Egyptian J. of Nutrition Vol. XXXIII No. 2 (2018)

\title{
Evaluation of Date Compote Prepared with Different Levels of Dibs and Milk
}

\author{
Ferweez, $H^{1}$ and $H$. A. Ismail ${ }^{2}$ \\ ${ }^{1}$ Food Sci. and Techno. Dept., Fac. of Agric., New Valley Branch, \\ Assiut University, Egypt. \\ ${ }^{2}$ Dairy Sci. and Techno. Dept., Fac. of Agric., New Valley Branch, \\ Assiut University, Egypt.
}

\begin{abstract}
Date compote manufacture supported by milk as source for the fat and protein and dibs as an alternative to sugar partial or whole, is highly nutritious and economically cheap. Therefore, this research was study the effect of fortification by different levels of milk $(0.0,25$ and $50 \%$ of date weight) and dibs by different levels as an alternative to sugar solution ( $0.0,50$, and $100 \%$ of sugar solution) on physiochemical and sensory evaluation of date compote.
\end{abstract}

The obtained results revealed that fortification of date compote by milk and replacement dibs as an alternative to sugar solution at different levels had a significant effect on physiochemical composition of date compote, i.e. total solids $\%$, total dietary fibers $\%$, total protein $\%$, total lipids $\%$, ash $\%$ and $\mathrm{pH}$ value; sugars composition of date compote, i.e. total sugars $\%$, reducing sugars $\%$, sucrose $\%$, glucose $\%$ and fructose $\%$ except glucose/fructose ratio; 


\section{Ferweez, $\mathrm{H}$ and $\mathrm{H}$. A. Ismail}

minerals composition of date compote, i.e. Potassium (K), , Sodium $(\mathrm{Na})$, Calcium (Ca) ,Magnesium (Mg) and Iron (Fe) contents (mg/100g); essential amino acids composition of date compote (histidine, isoleucine, leucine, lycine, methionine, phenylalanine, tryptophan and valine) and non-essential amino acids composition of date compote, i.e. alanine, arginine, aspartic, cysteine, glutamic, proline, serine and tyrosine and sensory evaluation of date compote (flavour, appearance, taste, and consistency).

Generally, it could be demonstrated from the results in this work that date compote supported by milk at $50 \%$ and dibs as alternative to sugar at $100 \%$ of date weight is the best ,accept ,highly nutritious .

\section{Introduction}

New Valley Governorate is one of the common governorates in Egypt in the production of dates (Phoenix dactylifera L.) about 45 a thousand tons. Egypt is producing 1.50 million tons of dates annually which represent $17.70 \%$ of the world production (FAO, 2017). The fruit of the dates are good sources of sugars, fiber, contain many important vitamins such as vitamin $\mathrm{C}$, pro-vitamin $\mathrm{A}$, and minerals, containing significant amounts of calcium, iron, fluorine, and selenium (Al-Shahib, and Marshall 2003). 


\section{Egyptian J. of Nutrition Vol. XXXIII No. 2 (2018)}

Dates are an important source of calories with about $78 \%$ carbohydrates $2-3 \%$ proteins and $1 \%$ fat (Nasehi et al., 2012). The major parts of the carbohydrates in dates are in the form of fructose and glucose (Ishurd and Kennedy, 2005). The fruit contained $32 \%$ glucose and $30 \%$ fructose, while the water-insoluble fibers of its flesh consisted of $49.9 \%$ lignin and $20.9 \%$ polysaccharides (Shafiei at el; 2010). The sugars in dates are easily digested and can immediately be moved to the blood after consumption and can quickly be metabolized to release energy for various cell activities (Khan et al., 2008). High date fruit consumption can reduced risk of several chronic diseases such as coronary heart disease, cardiovascular disease, cancer, aging, atherosclerosis, neurodegenerative disease, tumor, and mutagens (Al-Farsi and Lee, 2008 ; Gad et al ., 2010). Date has antitumor activity, antioxidant and anti-mutagenic properties (Abbes et al., 2013). Surplus dates are made into cubes, spread, paste, powder (date sugar), jam, jelly, juice, syrup, vinegar and alcohol. Dates are usually taken as such or with Arabian coffee, milk, or yoghurt, and are used in many bakery or confectionary products together with chocolate, coconut, honey and vinegar (Besbes et al., 2009).

Date syrup (Dibs) is a produced in home and village by extraction and boiling down of juice and on a semi and full industrial scale (FAO, 2017). It is product obtained from matured product with about $67-72 \%$ solid concentration consisting of $95 \%$ reducing sugar (Rofehgari-Nejad et al., 2010). Date syrup as the main and general by-product of date is used for foodstuffs such as jams, marmalades, 


\section{Ferweez, $\mathrm{H}$ and $\mathrm{H}$. A. Ismail}

concentrated beverages like dough, kashk, chocolates, ice cream, yoghurt dessert, confectioneries and honey, bakery products, sesame paste/date syrup blends, jam and some other like sweets, snacks, and health foods (El-Sharnouby, et al. , 2009). However, dates are known to be rich in carbohydrates (80\%) but quite low in protein among 2 to 3\% (Kaushik et al., 2016).

Milk has good quality protein such as caseins and whey proteins, which contain essential amino acids, fat and minerals. It has good amount of calcium and vitamins, specially vitamin A, B and C, riboflavin, niacin and folic acid, which are very important for biological processes and normal growth of body (Ismail, 2015). The milk which deficient in iron content compared with other food (Miguel, et al. 2003). Many studies had indicated that date and its processing by-products are good substrates for the production of dairy products. In this study date compote made from date flesh with date syrup (Dibs) substitute to sugar solution and fortified by milk attribute to improve the sensory characteristics and nutritional value of date compote that might be consumed as new functional product. Consequently, the aim of this study is to study effect of fortification by the different levels of date syrup (dibs) and milk on physiochemical and sensory parameters of date compote. 


\section{Egyptian J. of Nutrition Vol. XXXIII No. 2 (2018)}

\section{Materials and Methods}

This work was carried out in Foods \& Dairy Science and Technology departments Laboratories, Fac. Agric. New Valley Branch, Assuit University, Egypt, during 2016 and 2017 working seasons to evaluate effect of different levels of date syrup or dibs (as a sugar solution replacer) i.e. $0.0,50.0$ and $100 \%$ of the sugar solution and milk $(0.0,25.0$ and $50 \%$ of date weight) on physiochemical and sensory parameters of date compote. Sugar solution concentration used in processing of date compote is $65 \%$

\section{Materials}

\section{Date fruits}

Saidy cultivar of date (Phoenix dactylifera L.) high quality fruits at Tamr stage were sorted, obtained from the Elforqan Date Packing Factory, El-Kharga City, New Valley Governorate, Egypt.

\section{Milk}

Fresh evaporated cow's milk $(52.75 \%$ moisture, fat $13.93 \%$, protein $12.14 \%$, Lactose $18.16 \%$, ash $2.85 \%$, acidity $0.17 \%$ and $\mathrm{pH}$ 6.1) analyzed by Milk Scan (Bulgaria) .Milk was obtained from dairy farm of El-Kharga City, New Valley Governorate, Egypt. This milk was reduced to about one-fourth of its original volume by slow evaporation before use. 
Ferweez, $\mathrm{H}$ and $\mathrm{H}$. A. Ismail

\section{Methods}

\section{Preparation of date flesh and syrup (Dibs):}

According to (Kaushik1 et al. , 2016 ), date flesh was separated from kernel, then flesh was weighted and washed twice and remove excess water from it, this used in processing date compote and other part from washed date flesh was extracted by $1: 3$ (date flesh :water ) at $70^{\circ} \mathrm{C}$ for two hours with stirring at intervals. The produce juice was filtered in cheese clothes (double layer). Then, juice was concentrated using water bath at $70^{\circ} \mathrm{C}$ and stir it occasionally to avoid burning at the bottom until total soluble solids $\%$ (TSS\%) reach $75 \%$ and place in a cool condition for storage until use it. When used, dibs as an alternative to sugar solution $65 \%$ was diluted from $75 \%$ to $65 \%$ TSS\%.

\section{Preparation of date compote:}

Date compote is normally prepared by heating $1 \mathrm{~kg}$ date flesh in 1.5 liter sugar solution (65\%) or dibs (65\%) with / or without milk according to the studied previous treatments in a simultaneously using water bath at $70^{\circ} \mathrm{C}$ for 20 minutes with stirring at intervals as in Table (1).

The representative samples of date compote were packed in $500 \mathrm{ml}$ brown plastic containers and were kept in the refrigerator. The chemical analyses, physical characters, and sensory features were carried out on fresh date compote. 


\section{Egyptian J. of Nutrition Vol. XXXIII No. 2 (2018)}

Analytical methods of date flesh, dibs and date compote samples:

Total soluble solids (TSS) \% was determined by "Abbe" Refractometer at $20^{\circ} \mathrm{C}$. Moisture, ash, $\mathrm{pH}$; titratable acidity and dietary fiber content of date flesh and compote were quantified using procedure of the AOAC (2005) .

Protein was determined by Kjeldahl. The protein content was expressed as nitrogen multiplied by a factor $(6.25$ for date flesh or syrup and 6.38 for milk).

Sugars: Reducing sugar and total sugars were determined according to Lane and Eynon volumetric method using titration with Fehling's reagents (Ranganna, 1986).Non-reducing sugars content was calculated by difference. Mineral analysis: Calcium, Magnesium and Iron were determined using the Atomic absorption, while Potassium and Sodium were determined using Flame photometer as in $A O A C$ (2005).

\section{Lipid Extraction:}

Homogenized tissue $(10 \mathrm{~g})$ was progressively added to small amounts of a chloroform/methanol 2:1 ( $\mathrm{v} / \mathrm{v}$ ) mixture (up to $200 \mathrm{ml}$ ) as in AOAC (2005), with vigorous shaking, and then the extraction was carried on for a further $2 \mathrm{~h}$, using an electromagnetic stirrer. The mixture was filtered and the filter was rewashed with fresh solvent and pressed according to Folch method.

\section{Amino Acid Analysis:}

Amino acid analysis, using vapor $\mathrm{HCl}$ hydrolysis of samples and standards at $110^{\circ} \mathrm{C}$ for $19-20$ hours. After hydrolysis, samples submitted on PVDF are extracted three times with 100 microliters of $40 \%$ acetonitrile / $0.5 \%$ trifluoroacetic acid and the extracts dried 
Ferweez, $\mathrm{H}$ and $\mathrm{H}$. A. Ismail

completely in Speed vac before re-suspension in sample buffer. Amino acids were determined as $\mathrm{mg} / 100 \mathrm{~g}$ date compote on dry weight basis. Samples and standards are then analyzed using a Beckman 6300 system according to the official standard method (AOAC, 2005). Tryptophan amino acid was determined according to Vakaleris and Price (1959) and modified by Lin et al., (1982).

\section{Sensory evaluation of date compote:}

Representative samples were examined for sensory preference test in a hedonic scale of 10 points, where 1 (one) was for dislike very much and 10 (ten) for like very much. The sensory evaluation of the resultant samples was judged by 20 staff members and semi-trained panelists for taste, flavor, appearance and overall acceptability as described in El-Nagga and Abd El-Tawab (2012) with some modifications.

\section{Statistical analysis:}

The results of this study were analyzed using SPSS (Version 20) software. Data analysis method used for analysis of variance (ANOVA). Differences among treatments were evaluated according to procedure out lined by Gomez and Gomez (1983). Significant of difference between means was defined $(P<0.05)$ using Duncan's multiple range test. 


\section{Egyptian J. of Nutrition Vol. XXXIII No. 2 (2018)}

\section{Results and Discussion}

\section{Physicochemical composition of date flesh and date syrup (dibs):}

Analysis of date flesh as shown in Table (2) revealed that moisture, dry matter, dietary fiber, protein, lipids, ash and total sugar and reducing sugars content were within $21.69,78.31,8.34,1.72$, $2.04,1.85,74.95$ and $71.14 \%$, respectively. These results were, in general, comparable to those reported previously Borchani et al. (2010) and Assirey (2015). Al-Hooti et al. (1997) found date flesh contains protein content very little, and therefore not a good source of protein. Although date flesh had relatively low protein, fat and ash contents, it's had a high amount of reducing sugars namely fructose and glucose. The low lipid content compared with the high sugar content of dates is a good indicator for its potential uses. Date flesh was a super source of dietary fiber $(8.34 \%$ on dry weight basis ,DWB).Dietary fibers diets are associated with the prevention of some diseases for example constipation, colonic cancer, diverticular disease, coronary heart disease, cardiovascular disease, atherosclerosis, diabetes and obesity (Al-Farsi et al., 2007). As well dietary fiber concentration should have a balanced content of soluble and insoluble fraction (Hasnaoui et al., 2012). This is necessary for food industry and ability to transformation on new products is available in the markets.

Also in Table (2) illustrate the chemical of date syrup (Dibs). It was found that the moisture content of dibs was $35.33 \%$ while, dry matter, dietary fiber, protein, lipids, ash, total sugar and reducing sugars contents of dibs were 64.67, 0.59, 1.03, 2.33, 1.71, 55.09 and $51.35 \%$, respectively. The above data showed that total sugars and 
Ferweez, $\mathrm{H}$ and $\mathrm{H}$. A. Ismail

reducing sugars contents were the highest values of the date syrup. Generally date syrup contained low fat, protein, ash and dietary fiber. These results are in agreement with previous studies El.Nagga and Abd El.Tawab (2012).

According to this study the major part of date syrup consisted of reducing sugars, fructose and glucose as predominant sugars. These sugars have more advantages in comparison with sucrose (Sugar) on health since they are having higher sweetness (Ghafari et al., 2013), which are easily absorbed by the human body. So, date syrup considered as good and healthy replacement for sugar in processing of compote. These data are in same trend with those reported by Raiesi Ardali et al.(2014).

\section{Physiochemical composition of date compote fortification and replacement by different levels of milk and dibs:}

Data tabulated in Table( 3 ) shows the effect of fortification by milk, irrespective of replacement by dibs on physiochemical composition for date compote, i.e. total solids $\%$, total dietary fibers $\%$, total protein $\%$, total lipids $\%$ and ash $\%$. The results revealed that increasing fortification of date compote by milk from zero to 25 and $50 \%$ of date weight led to an increase in total protein \% of date compote by 39.79 and $79.03 \%$, total lipids \% of date compote by 30.72 and $55.56 \%$ and ash \% of date compote by 9.82 and $18.30 \%$ of the control value (without or zero milk), respectively. This finding might be due to milk was a good source of protein and lipids, In contrast, Date flesh contained trace amounts of protein and lipids (Kaushik et al., 2016). Also, results indicated that increasing quantity fortification of date compote by milk from zero to 25 and $50 \%$ of date weight led to decrease in total solids \% by 7.52 and $12.76 \%$ as well as total dietary fibers of by 3.37 and $4.01 \%$ and $\mathrm{pH}$ value by 3.63 


\section{Egyptian J. of Nutrition Vol. XXXIII No. 2 (2018)}

and $7.74 \%$ of the control value (without or zero milk), respectively. This decrease might be attribute to that milk is a poor source of dietary fibers; in contrast, milk contained moderate amounts of moisture.

Data for the effect of replacement of sugar solution by dibs on physiochemical composition of date compote, irrespective of fortification by milk, are shown in Table (3). Results cleared that replaced dibs level had a significant effect on the all previous traits. The present results indicated that increasing replacement of dibs level from zero to 50 and $100 \%$ of sugar solution led to an increase in total solids $\%$ of date compote by 1.20 and $1.97 \%$, total protein $\%$ of date compote by 7.53 and $18.41 \%$, total lipids $\%$ by 3.32 and $23.20 \%$ and ash \% by 18.27 and $34.62 \%$ of the control value (without or zero dibs), respectively. Also, results indicated that increasing quantity replacement of date compote by dibs from zero to 50 and $100 \%$ of date weight led to decrease in total dietary fibers by 1.97 and $5.31 \%$ and $\mathrm{pH}$ value of date compote by 4.83 and $6.47 \%$ of the control value (without or zero dibs), respectively. This result might be due to date flesh was a good source of dietary fiber, in contrast, dibs contained trace amounts of total dietary fiber. These results are in the line with that reported by Raiesi Ardali et al.(2014) .

\section{Effect of fortification and replacement by different levels of milk} and dibs on sugars composition of date compote:

Data tabulated in Table (4) shows the effect of fortification by milk, irrespective of replacement by dibs on sugars composition of date compote, i.e. total sugars $\%$, reducing sugars $\%$, sucrose $\%$, glucose $\%$, fructose $\%$ and glucose/fructose ratio. Results cleared that fortification level by milk had a significant effect on the all studied traits except glucose/fructose ratio. The data showed that increasing 
Ferweez, $\mathrm{H}$ and $\mathrm{H}$. A. Ismail

fortification of date compote by milk from zero to 25 and $50 \%$ led to decrease in total sugars of date compote by 10.11 to $7.69 \%$; reducing sugars by 12.48 to $8.26 \%$; sucrose by 28.83 to $17.05 \%$ and; glucose by 19.68 to $9.03 \%$ and fructose by 19.43 to $11.10 \%$ by comparison the control compote, respectively. This decrease in the previous traits might be attribute to milk was a weak source of total sugars (glucose and fructose) and sucrose. These findings are in the same line with those reported by Guetouache et al.( 2014).

With regard to effect of replacement of sugar solution by dibs on chemical composition of date compote, irrespective of fortification by milk, are shown in Table (4). Data cleared that replaced dibs level had significant effect on all previous traits. The recorded data indicated that increasing replacement of dibs level from zero to 50 and $100 \%$ of sugar solution led to an increase in total sugars $\%$ of date compote by 2.42 and $4.68 \%$, reducing sugars $\%$ of date compote increased by 2.51 and $7.62 \%$, glucose $\%$ of date compote increased by 7.57 and $15.96 \%$ and fructose $\%$ of date compote increased by 5.61 and $15.32 \%$ of the control value (without or zero dibs), respectively. Also, results indicated that increasing quantity replacement of date compote by dibs from zero to 50 and $100 \%$ of date weight led to decrease in sucrose $\%$ of date compote by 101.20 and $280.54 \%$, respectively. This finding might be due to Date flesh and dibs was a good sources of total sugars, glucose and fructose contents, in contrast, date flesh and dibs contained little amounts of sucrose content, might be during the maturation process sucrose converted to glucose and fructose. These results are in the line with that reported by El-Nagga and Abd El-Tawab (2012) and Raiesi Ardali et al.(2014). 


\section{Egyptian J. of Nutrition Vol. XXXIII No. 2 (2018)}

Effect of fortification and replacement by different levels of milk and dibs on minerals composition of date compote:

Data presented in Table (5) demonstrated the effect of fortification by milk, irrespective of replacement by dibs on minerals composition of date compote, i.e. $\mathrm{K}, \mathrm{Na}, \mathrm{Ca}, \mathrm{Mg}$ and Fe contents $(\mathrm{mg} / 100 \mathrm{~g})$. Results clarified that fortification level by milk had a significant effect on the all studied minerals. Data demonstrated that increasing fortification of date compote by milk from zero to 25 and $50 \%$ of date weight led to decrease in $\mathrm{K}$ content of date compote by 7.52 and $12.76 \%$ and $\mathrm{Na}$ content by 8.54 and $4.01 \%$ of the control value (without or zero milk), respectively. In addition, data indicated that fortification of date compote by milk from zero to 25 and $50 \%$ of date weight led to an increase in Ca content of date compote by 39.79 and $79.03 \%$; $\mathrm{Mg}$ content of date compote increased by 30.72 and $55.56 \%$ and $\mathrm{Fe}$ content of date compote increased by 9.82 and $18.30 \%$, respectively. This increase in the previous traits might be attribute to that milk was a good source of $\mathrm{Ca}$ and $\mathrm{Mg}$ contents. These findings are in the same line with those reported by The obtained data are in close agreement that reported by Soliman, (2005).

Regarding effect of replacement of sugar solution by dibs on minerals composition of date compote, irrespective of fortification by milk, was shown in Table (5). Data indicated that replaced dibs level had a significant effect on all previous minerals. The found results showed that increasing replacement of dibs level from zero to 50 and $100 \%$ of sugar solution led to increase in $\mathrm{K}$ content of date compote by 1.20 and $1.97 \%$; Ca content by 7.53 and $18.41 \%$; Mg content by 3.32 and $23.20 \%$ and Fe content by 18.27 and $34.62 \%$ of the control value (without or zero dibs), respectively. Also, results indicated that increasing quantity replacement of date compote by 
dibs from zero to 50 and $100 \%$ of date weight led to decrease in $\mathrm{Na}$ content of date compote by 1.97 and $5.31 \%$, respectively. These increase in the previous traits might be attribute to that date flesh was a good source of $\mathrm{Ca} ; \mathrm{Mg} ; \mathrm{K}$ and $\mathrm{Fe}$ contents. The obtained data are in close agreement that reported by Gad et al., (2010). El-Nagga and Abd El - Tawab (2012) and Tang, et al. (2014) revealed that Saidy date flesh was a good source for many elements, such as $\mathrm{K}$ (1000), Ca (28.5), Mg (52.0), Na (90.5), Zn (0.95) and Fe (10.0 $\mathrm{mg} / 100 \mathrm{~g}$ of fresh weight). They added that the date is considered as a practical supplement for iron rather than iron tablets for those who have iron deficiency because it does not show side effects.

\section{Effect of fortification and replacement by different levels of milk and dibs on essential and non- essential amino acids contents of date compote:}

Data given in Tables (6\&7) showed the effect of fortification by milk, irrespective of replacement by dibs on essential amino acids composition of date compote ( histidine, isoleucine, leucine, lycine , methionine, phenylalanine tryptophan and valine ) and non-essential amino acids composition of date compote, i.e. alanine, arginine, aspartic, cysteine, glutamic, proline, serine and tyrosine . Results indicated that fortification level by milk had a significant effect on all studied essential and non-essential amino acids contents of date compote. Data demonstrated that increasing fortification of date compote by milk from zero to 25 and $50 \%$ of date weight led to increase in all studied essential and non-essential amino acids contents of date compote. This result might be attributed to that milk was a good source of essential and non-essential amino acids contents. These findings are in agreement with those reported by Guetouache et al. (2014). 


\section{Egyptian J. of Nutrition Vol. XXXIII No. 2 (2018)}

Concerning effect of replacement of sugar solution by dibs on essential amino acids composition of date compote and nonessential amino acids. Results demonstrated that replaced dibs level had a significant effect on all studied essential and non-essential amino acids contents of date compote except alanine, arginine and aspartic acids were no significant, irrespective of fortification by milk (Tables 6\&7) .The scored results showed that increasing replacement of dibs level from zero to 50 and $100 \%$ of sugar solution led to an increase in all studied essential and non-essential amino acids contents of date compote except alanine, arginine and aspartic acids. These results are in the same line with that reported by $\mathbf{A l}$ Farsi and Lee (2008) and El-Sohaimy and Hafez (2010).

Effect of fortification and replacement by different levels of milk and dibs on sensory evaluation of date compote:

Results given in Table (8) showed the effect of fortification by milk, irrespective of replacement by dibs on sensory parameters of date compote (flavour, appearance, taste, and consistency). Data pointed out that fortification level by milk had a significant effect on the all studied sensory parameters of date compote. Data indicated that increasing fortification of date compote by milk from zero to 25 and $50 \%$ of date weight led to increase in flavor of date compote by 5.60 and $9.17 \%$; appearance by 13.74 and $14.38 \%$; taste by 2.36 and $4.98 \%$ and consistency by 3.52 and $6.36 \%$ of the control value (zero or without milk). The highest increase in the sensory parameters of date compote was recorded for the appearance of product. This result might be attributed to that colour of milk is white. These findings are in the same line with those reported by Barłowska et al., (2011). 
Ferweez, $\mathrm{H}$ and $\mathrm{H}$. A. Ismail

Regarding effect of replacement of sugar solution by dibs on sensory parameters of date compote, irrespective of fortification by milk, are shown in Table (8). Data indicated that replaced dibs level had a significant effect on the all studied sensory evaluation properties, i.e. flavor, appearance, taste and consistency. The found results showed that increasing replacement of dibs level from zero to $100 \%$ of sugar solution led to an increase in flavour by 10.11 to $15.78 \%$; taste by 19.97 to $25.42 \%$; consistency by 2.60 to $5.19 \%$ to control compote (without or zero dibs) to dibs compote, respectively. This increase in the previous traits might be attribute to those dibs was a good source of total sugars and especially fructose content. Also, results indicated that increasing quantity replacement of date compote by dibs from zero to 50 and $100 \%$ of sugar solution to decrease in appearance of date compote by $5.95 \%$, to 1.75 , respectively. This result might be expected due to the colour of dibs is brownish. The obtained data are in agreement with those reported by Soliman, (2005) and Amiri et al. (2014) for yoghourt incorporation by date palm paste and ice cream fortified with dibs .

\section{Conclusion}

Milk is having high nutritive value as it contains fat and water soluble vitamins, minerals, proteins and lipids. Date fruits are considered as a good source of sugars, fiber, minerals and other substances, but quite low in protein and fat. Also, Date syrup characterized with its higher calories, vitamins and minerals; Combination of them in date compote provides a highly nutritive product with benefits to gather.The recorded results in this work indicated that date compote supported by milk at $50 \%$ of date weight as source for the fat and protein and dibs at $100 \%$ of date weight as an alternative to sugar solution is the best, highly nutritious. 


\section{Egyptian J. of Nutrition Vol. XXXIII No. 2 (2018)}

Table (1): Components weight of date compote for sugar solution replacement by dibs and fortification by Milk

\begin{tabular}{c|c|c|c|c|c}
\hline $\begin{array}{c}\text { Sam } \\
\text { ple }\end{array}$ & $\begin{array}{c}\text { Date } \\
\text { weight } \\
(\mathrm{g})\end{array}$ & $\begin{array}{c}\text { Sugar solution } \\
65 \% \text { weight }(\mathrm{g})\end{array}$ & $\begin{array}{c}\text { Dibs 65\%weight } \\
\% \text { of Sugar } \\
\text { solution weight }\end{array}$ & $\begin{array}{c}\text { milk weight } \\
(\mathrm{g}) \% \text { of date } \\
\text { weight }\end{array}$ & $\begin{array}{c}\text { Total date } \\
\text { compote } \\
\text { weight(g) }\end{array}$ \\
\hline T1 & 1000 & $1500 \mathrm{~g}$ & Zero & Zero & $2500 \mathrm{~g}$ \\
\hline T2 & 1000 & $1250 \mathrm{~g}$ & Zero & $25 \%(250 \mathrm{~g})$ & $2500 \mathrm{~g}$ \\
\hline T3 & 1000 & $1000 \mathrm{~g}$ & Zero & $50 \%(500 \mathrm{~g})$ & $2500 \mathrm{~g}$ \\
\hline T4 & 1000 & $750 \mathrm{~g}$ & $50 \%(750 \mathrm{~g})$ & Zero & $2500 \mathrm{~g}$ \\
\hline T5 & 1000 & $500 \mathrm{~g}$ & $50 \%(750 \mathrm{~g})$ & $25 \%(250 \mathrm{~g})$ & $2500 \mathrm{~g}$ \\
\hline T6 & 1000 & $250 \mathrm{~g}$ & $50 \%(750 \mathrm{~g})$ & $50 \%(500 \mathrm{~g})$ & $2500 \mathrm{~g}$ \\
\hline T7 & 1000 & Zero g & $100 \%(1500 \mathrm{~g})$ & Zero & $2500 \mathrm{~g}$ \\
\hline T8 & 1000 & Zero g & $100 \%(1250 \mathrm{~g})$ & $25 \%(250 \mathrm{~g})$ & $2500 \mathrm{~g}$ \\
\hline T9 & 1000 & Zero g & $100 \%(1000 \mathrm{~g})$ & $50 \%(500 \mathrm{~g})$ & $2500 \mathrm{~g}$ \\
\hline
\end{tabular}

Control of date compote samples was prepared without dibs and milk (T1). When samples contained zero dibs + milk $25 \%$ (T2) , zero dibs + milk 50\% (T3), dibs $50 \%$ + zero milk (T4), dibs $50 \%+$ milk $25 \%$ (T5), dibs 50\% + milk 50\% (T6), dibs $100 \%+$ zero milk (T7) , dibs 100\% + milk 25\% (T8) and dibs 100\% + milk 50\% (T9)

Table (2): Chemical properties of date flesh and date syrup (Dibs)

\begin{tabular}{|c|c|c|c|}
\hline \multicolumn{2}{|r|}{ Chemical composition } & Date flesh & $\begin{array}{c}\text { Date syrup( Dibs) } \\
65 \%\end{array}$ \\
\hline \multicolumn{2}{|r|}{ Moisture } & $21.69 \pm 0.20$ & $35.33 \pm 0.29$ \\
\hline \multicolumn{2}{|r|}{ Dry matter } & $78.31 \pm 0.20$ & $64.67 \pm 0.30$ \\
\hline \multicolumn{2}{|r|}{ Dietary fiber\% } & $8.34 \pm 0.11$ & $0.59 \pm 0.04$ \\
\hline \multicolumn{2}{|r|}{ Protein \% } & $1.72 \pm 0.03$ & $1.03 \pm 0.07$ \\
\hline \multicolumn{2}{|r|}{ Lipids\% } & $2.04 \pm 0.05$ & $2.33 \pm 0.09$ \\
\hline \multicolumn{2}{|r|}{ Ash\% } & $1.85 \pm 0.06$ & $1.71 \pm 0.02$ \\
\hline \multicolumn{2}{|r|}{ Total sugar\% } & $74.95 \pm 0.15$ & $55.09 \pm 0.37$ \\
\hline \multicolumn{2}{|r|}{ Reducing sugars $\%$} & $71.14 \pm 0.08$ & $51.35 \pm 0.29$ \\
\hline \multirow{4}{*}{ Sugars } & sucrose $\%$ & $1.93 \pm 0.04$ & $2.04 \pm 0.07$ \\
\hline & glucose $\%$ & $33.68 \pm 0.18$ & $25.99 \pm 0.70$ \\
\hline & fructose $\%$ & $31.22 \pm 0.30$ & $23.12 \pm 0.20$ \\
\hline & glucose / fructose & $1.08 \pm 0.01$ & $1.11 \pm 0.03$ \\
\hline
\end{tabular}

Values are expressed as the mean standard deviation of four determinations 
Ferweez, $\mathrm{H}$ and $\mathrm{H}$. A. Ismail

Table (3): Physiochemical composition of date compote made from different levels of milk and dibs

\begin{tabular}{|c|c|c|c|c|c|}
\hline \multirow{2}{*}{ Indigenous } & \multirow{2}{*}{$\begin{array}{c}\text { Milk } \\
\text { Treatments }\end{array}$} & \multicolumn{3}{|c|}{ Treatments of sugar replacer } & \multirow{2}{*}{ Mean $\pm S D$} \\
\hline & & Zero dibs & $50 \%$ dibs & $100 \%$ dibs & \\
\hline \multirow{4}{*}{$\begin{array}{l}\text { Total } \\
\text { solids\% }\end{array}$} & Zero milk & $77.96 \pm 0.72 \mathrm{~b}$ & $79.48 \pm 0.46 \mathrm{a}$ & $80.13 \pm 0.246 \mathrm{a}$ & $79.19 \pm 0.25 \mathrm{a}$ \\
\hline & Milk 25\% & $73.06 \pm 0.84 \mathrm{a}$ & $73.86 \pm 0.17 \mathrm{a}$ & $74.07 \pm 0.18 \mathrm{a}$ & $73.65 \pm 0.27 b$ \\
\hline & Milk 50\% & $69.82 \pm 0.76 \mathrm{a}$ & $70.20 \pm 0.12 \mathrm{ab}$ & $70.97 \pm 0.16 \mathrm{a}$ & $70.23 \pm 0.34 \mathrm{c}$ \\
\hline & ean $\pm S D$ & $73.61 \pm 0.33 \mathrm{c}$ & $74.49 \pm 0.20 \mathrm{~b}$ & $75.06 \pm 0.06$ & \\
\hline \multirow{4}{*}{$\begin{array}{c}\text { Total } \\
\text { Dietary } \\
\text { fiber \% }\end{array}$} & Zero & $6.88 \pm 0.11 \mathrm{a}$ & $6.81 \pm 0.13 a$ & $6.53 \pm 0.05 b$ & $6.74 \pm 0.05 \mathrm{a}$ \\
\hline & Milk 25\% & $6.68 \pm 0.03 \mathrm{a}$ & $6.53 \pm 0.06 \mathrm{~b}$ & $6.35 \pm 0.07 \mathrm{c}$ & $6.52 \pm 0.05 \mathrm{~b}$ \\
\hline & Milk 50\% & $6.66 \pm 0.05 \mathrm{a}$ & $6.48 \pm 0.03 \mathrm{~b}$ & $6.31 \pm 0.02 \mathrm{c}$ & $6.48 \pm 0.03 \mathrm{c}$ \\
\hline & Mean $\pm S D$ & $6.74 \pm 0.02 \mathrm{a}$ & $6.61 \pm 0.06 \mathrm{~b}$ & $6.40 \pm 0.04 \mathrm{c}$ & \\
\hline \multirow{4}{*}{$\begin{array}{c}\text { Total } \\
\text { protein } \%\end{array}$} & Zero & $1.78 \pm 0.03 \mathrm{~b}$ & $1.84 \pm 0.06 \mathrm{~b}$ & $2.00 \pm 0.05 a$ & $1.86 \pm 0.04 \mathrm{c}$ \\
\hline & Milk 25\% & $2.33 \pm 0.27 \mathrm{~b}$ & $2.55 \pm 0.28 \mathrm{ab}$ & $2.93 \pm 0.09 a$ & $2.60 \pm 0.19 \mathrm{~b}$ \\
\hline & Milk 50\% & $3.05 \pm 0.08 \mathrm{c}$ & $3.33 \pm 0.12 \mathrm{~b}$ & $3.60 \pm 0.15 \mathrm{a}$ & $3.33 \pm 0.11 \mathrm{a}$ \\
\hline & Mean \pm SD & $2.39 \pm 0.10 \mathrm{~b}$ & $2.57 \pm 0.13 \mathrm{~b}$ & $2.83 \pm 0.10 \mathrm{a}$ & \\
\hline \multirow{4}{*}{$\begin{array}{c}\text { Total lipids } \\
\%\end{array}$} & Zero & $1.49 \pm 0.07 \mathrm{a}$ & $1.49 \pm 0.06 \mathrm{a}$ & $1.60 \pm 0.02 \mathrm{a}$ & $1.53 \pm 0.03 \mathrm{c}$ \\
\hline & Milk 25\% & $1.87 \pm 0.08 \mathrm{~b}$ & $1.91 \pm 0.04 b$ & $2.21 \pm 0.100 \mathrm{a}$ & $2.00 \pm 0.04 \mathrm{~b}$ \\
\hline & Milk 50\% & $2.08 \pm 0.04 \mathrm{c}$ & $2.20 \pm 0.05 \mathrm{~b}$ & $2.85 \pm 0.07 \mathrm{a}$ & $2.38 \pm 0.04 \mathrm{a}$ \\
\hline & Mean $\pm S D$ & $1.81 \pm 0.03 \mathrm{~b}$ & $1.87 \pm 0.01 \mathrm{~b}$ & $2.23 \pm 0.05 \mathrm{a}$ & \\
\hline \multirow{4}{*}{ Ash \% } & Zero & $1.91 \pm 0.05 \mathrm{c}$ & $2.19 \pm 0.07 b$ & $2.61 \pm 0.02 \mathrm{a}$ & $2.24 \pm 0.01 \mathrm{c}$ \\
\hline & Milk 25\% & $2.09 \pm 0.03 \mathrm{c}$ & $2.42 \pm 0.12 \mathrm{~b}$ & $2.86 \pm 0.05 \mathrm{a}$ & $2.46 \pm 0.05 \mathrm{~b}$ \\
\hline & Milk 50\% & $2.23 \pm 0.04 \mathrm{c}$ & $2.77 \pm 0.08 \mathrm{~b}$ & $2.94 \pm 0.03 \mathrm{a}$ & $2.65 \pm 0.02 \mathrm{a}$ \\
\hline & Mean \pm SD & $2.08 \pm 0.01 \mathrm{c}$ & $2.46 \pm 0.07 \mathrm{~b}$ & $2.80 \pm 0.04 \mathrm{a}$ & \\
\hline \multirow{4}{*}{$\mathrm{pH}$ value } & Zero & $5.65 \pm 0.05 \mathrm{a}$ & $5.35 \pm 0.05 b$ & $5.28 \pm 0.03 b$ & $5.43 \pm 0.17 \mathrm{a}$ \\
\hline & Milk 25\% & $5.45 \pm 0.05 \mathrm{a}$ & $5.17 \pm 0.03 \mathrm{~b}$ & $5.12 \pm 0.03 \mathrm{~b}$ & $5.24 \pm 0.16 \mathrm{~b}$ \\
\hline & Milk 50\% & $5.18 \pm 0.03 \mathrm{a}$ & $5.03 \pm 0.06 \mathrm{~b}$ & $4.90 \pm 0.10 \mathrm{~b}$ & $5.04 \pm 0.14 \mathrm{c}$ \\
\hline & Mean \pm SD & $5.43 \pm 0.01 \mathrm{a}$ & $5.18 \pm 0.02 \mathrm{~b}$ & $5.10 \pm 0.03 \mathrm{c}$ & \\
\hline
\end{tabular}

Values are expressed as the mean standard deviation of three determinations a b c d e Letters indicate significant differences between date compote treatments 


\section{Egyptian J. of Nutrition Vol. XXXIII No. 2 (2018)}

Table (4) : Sugars composition of date compote made from different levels of milk and dibs

\begin{tabular}{|c|c|c|c|c|c|}
\hline \multirow{2}{*}{ Indigenous } & \multirow{2}{*}{ Milk Treatments } & \multicolumn{3}{|c|}{ Treatments of sugar replacer } & \multirow{2}{*}{ Mean $\pm S D$} \\
\hline & & Zero dibs & $50 \%$ dibs & $100 \%$ dibs & \\
\hline \multirow{4}{*}{$\begin{array}{c}\text { Total } \\
\text { sugars } \\
\%\end{array}$} & n & $6.95 \pm 0.57 \mathrm{c}$ & $8.27 \pm 0.56 \mathrm{~b}$ & $70.28 \pm 0.31 \mathrm{a}$ & $0.07 \mathrm{a}$ \\
\hline & Milk 25\% & $62.24 \pm 0.45 c$ & $63.60 \pm 0.28 \mathrm{~b}$ & $64.99 \pm 0.42 \mathrm{a}$ & $63.61 \pm 0.20 \mathrm{~b}$ \\
\hline & Milk 50\% & $59.46 \pm 0.15 c$ & $61.33 \pm 0.32 \mathrm{~b}$ & $62.21 \pm 0.24 \mathrm{a}$ & $0.24 \mathrm{c}$ \\
\hline & ean \pm SD & $62.88 \pm 0.30 \mathrm{c}$ & $64.40 \pm 0.06 \mathrm{~b}$ & $65.82 \pm 0.23 \mathrm{a}$ & \\
\hline \multirow{4}{*}{$\begin{array}{c}\text { Reducing } \\
\text { sugars } \\
\%\end{array}$} & Zero & $57.04 \pm 0.23 \mathrm{c}$ & $59.56 \pm 0.20 \mathrm{~b} \mathrm{~b}$ & $62.65 \pm 0.12 \mathrm{a}$ & $59.75 \pm 0.08 \mathrm{a}$ \\
\hline & Milk 25\% & $53.84 \pm 0.28 \mathrm{c}$ & $54.64 \pm 0.24 \mathrm{~b}$ & $57.08 \pm 0.14 \mathrm{a}$ & $55.19 \pm 0.16 \mathrm{~b}$ \\
\hline & Milk 50\% & $51.68 \pm 0.10 \mathrm{~b}$ & $52.45 \pm 0.20 \mathrm{~b}$ & $55.23 \pm 0.78 \mathrm{a}$ & $53.12 \pm 0.20 \mathrm{c}$ \\
\hline & Mean \pm SD & $54.19 \pm 0.17 \mathrm{c}$ & $55.55 \pm 0.09 \mathrm{~b}$ & $58.32 \pm 0.24 \mathrm{a}$ & \\
\hline \multirow{4}{*}{$\begin{array}{c}\text { Sucrose } \\
\%\end{array}$} & Zero & $9.83 \pm 0.12 \mathrm{a}$ & $4.59 \pm 0.27 b$ & $2.47 \pm 0.27 \mathrm{c}$ & $5.63 \pm 0.13 \mathrm{a}$ \\
\hline & Milk 25\% & $8.12 \pm 0.06 \mathrm{a}$ & $4.09 \pm 0.16 \mathrm{~b}$ & $2.21 \pm 0.12 \mathrm{c}$ & $4.81 \pm 0.07 \mathrm{~b}$ \\
\hline & Milk 50\% & $7.27 \pm 0.15 \mathrm{a}$ & $3.88 \pm 0.14 \mathrm{~b}$ & $1.96 \pm 0.08 \mathrm{c}$ & $4.37 \pm 0.12 c$ \\
\hline & Mean \pm SD & $8.41 \pm 0.08 \mathrm{a}$ & $4.18 \pm 0.18 \mathrm{~b}$ & $2.21 \pm 0.05$ c & \\
\hline \multirow{4}{*}{$\begin{array}{c}\text { Glucose } \\
\%\end{array}$} & Zero & $23.98 \pm 0.28 c$ & $26.07 \pm 0.06 \mathrm{~b}$ & $28.59 \pm 0.26 \mathrm{a}$ & $26.21 \pm 0.17 \mathrm{a}$ \\
\hline & Milk 25\% & $22.47 \pm 0.46 \mathrm{c}$ & $24.03 \pm 0.43 \mathrm{~b}$ & $25.62 \pm 0.12 \mathrm{a}$ & $24.04 \pm 0.29 \mathrm{~b}$ \\
\hline & Milk 50\% & $20.46 \pm 0.42 \mathrm{c}$ & $21.86 \pm 0.10 \mathrm{~b}$ & $23.39 \pm 0.15 \mathrm{a}$ & $21.90 \pm 0.22 c$ \\
\hline & Mean \pm SD & $22.30 \pm 0.26 \mathrm{c}$ & $23.99 \pm 0.13 b$ & $25.86 \pm 0.11 \mathrm{a}$ & \\
\hline \multirow{4}{*}{$\begin{array}{c}\text { Fructose } \\
\%\end{array}$} & Zero & $22.92 \pm 0.27 \mathrm{c}$ & $23.95 \pm 0.14 \mathrm{~b}$ & $25.79 \pm 0.11 \mathrm{a}$ & $24.22 \pm 0.17 \mathrm{a}$ \\
\hline & Milk 25\% & $20.13 \pm 0.40 \mathrm{c}$ & $21.83 \pm 0.17 b$ & $23.73 \pm 0.30 \mathrm{a}$ & $21.80 \pm 0.11 \mathrm{~b}$ \\
\hline & Milk 50\% & $19.00 \pm 0.19 \mathrm{c}$ & $19.78 \pm 0.13 \mathrm{~b}$ & $22.07 \pm 0.09 \mathrm{a}$ & $20.28 \pm 0.13 \mathrm{c}$ \\
\hline & Mean \pm SD & $20.69 \pm 0.10 \mathrm{c}$ & $21.85 \pm 0.05 b$ & $23.86 \pm 0.11 \mathrm{a}$ & \\
\hline \multirow{4}{*}{$\begin{array}{c}\text { Glucose/ } \\
\text { Fructose } \\
\text { ratio }\end{array}$} & Zero & $1.05 \pm 0.02 \mathrm{~b}$ & $1.09 \pm 0.01 \mathrm{a}$ & $1.11 \pm 0.01 \mathrm{a}$ & $1.08 \pm 0.01 \mathrm{a}$ \\
\hline & Milk 25\% & $1.12 \pm 0.03 \mathrm{a}$ & $1.10 \pm 0.01 \mathrm{a}$ & $1.08 \pm 0.01 \mathrm{~b}$ & $1.10 \pm 0.01 \mathrm{a}$ \\
\hline & Milk 50\% & $1.08 \pm 0.02 \mathrm{ab}$ & $1.11 \pm 0.003 \mathrm{a}$ & $1.06 \pm 0.01 \mathrm{~b}$ & $1.08 \pm 0.01 \mathrm{a}$ \\
\hline & Mean \pm SD & $1.08 \pm 0.01 \mathrm{~b}$ & $1.10 \pm 0.003 \mathrm{a}$ & $1.08 \pm 0.01 \mathrm{~b}$ & \\
\hline
\end{tabular}

Values are expressed as the mean standard deviation of three determinations

a b c d e Letters indicate significant differences between date compote treatments 
Ferweez, $\mathrm{H}$ and $\mathrm{H}$. A. Ismail

Table (5): Minerals composition $(\mathrm{mg} / 100 \mathrm{~g}$ ) of date compote made from different levels of milk and dibs

\begin{tabular}{|c|c|c|c|c|c|}
\hline \multirow{2}{*}{$\begin{array}{l}\text { Minerals } \\
(\mathrm{mg} / 100 \mathrm{~g})\end{array}$} & \multirow{2}{*}{ Milk Treatments } & \multicolumn{3}{|c|}{ Treatments of sugar replacer } & \multirow{2}{*}{ Mean $\pm S D$} \\
\hline & & Zero dibs & $50 \%$ dibs & $100 \%$ dibs & \\
\hline \multirow{4}{*}{ Potassium (K) } & Zero milk & $77.96 \pm 0.72 b$ & $79.48 \pm 0.46 \mathrm{a}$ & $80.13 \pm 0.246 \mathrm{a}$ & $79.19 \pm 0.25 \mathrm{a}$ \\
\hline & Milk 25\% & $73.06 \pm 0.84 \mathrm{a}$ & $73.86 \pm 0.17 \mathrm{a}$ & $74.07 \pm 0.18 \mathrm{a}$ & $73.65 \pm 0.27 b$ \\
\hline & Milk 50\% & $69.82 \pm 0.76$ a & $70.20 \pm 0.12 \mathrm{ab}$ & $70.97 \pm 0.16 \mathrm{a}$ & $70.23 \pm 0.34 \mathrm{c}$ \\
\hline & Mean $\pm S D$ & $73.61 \pm 0.33 \mathrm{c}$ & $74.49 \pm 0.20 \mathrm{~b}$ & $75.06 \pm 0.06$ & \\
\hline \multirow{4}{*}{ Sodium (Na) } & Zero & $6.88 \pm 0.11 \mathrm{a}$ & $6.81 \pm 0.13 \mathrm{a}$ & $6.53 \pm 0.05 b$ & $6.74 \pm 0.05 \mathrm{a}$ \\
\hline & Milk 25\% & $6.68 \pm 0.03 \mathrm{a}$ & $6.53 \pm 0.06 \mathrm{~b}$ & $6.35 \pm 0.07 c$ & $6.21 \pm 0.05 b$ \\
\hline & Milk 50\% & $6.66 \pm 0.05 \mathrm{a}$ & $6.48 \pm 0.03 \mathrm{~b}$ & $6.31 \pm 0.02 \mathrm{c}$ & $6.48 \pm 0.03 \mathrm{c}$ \\
\hline & Mean \pm SD & $6.74 \pm 0.02 \mathrm{a}$ & $6.61 \pm 0.06 \mathrm{~b}$ & $6.40 \pm 0.04 \mathrm{c}$ & \\
\hline \multirow{4}{*}{ Calcium (Ca) } & Zero & $17.8 \pm 0.03 \mathrm{~b}$ & $18.4 \pm 0.06 \mathrm{~b}$ & $20.0 \pm 0.05 \mathrm{a}$ & $18.7 \pm 0.04 \mathrm{c}$ \\
\hline & Milk 25\% & $23.3 \pm 0.27 b$ & $25.5 \pm 0.28 \mathrm{ab}$ & $29.3 \pm 0.09 \mathrm{a}$ & $26.0 \pm 0.19 \mathrm{~b}$ \\
\hline & Milk 50\% & $30.5 \pm 0.08 \mathrm{c}$ & $33.3 \pm 0.12 b$ & $36.0 \pm 0.15 \mathrm{a}$ & $\overline{33.3 \pm 0.11 \mathrm{a}}$ \\
\hline & Mean $\pm S D$ & $23.9 \pm 0.10 \mathrm{~b}$ & $25.7 \pm 0.13 \mathrm{~b}$ & $28.3 \pm 0.10 \mathrm{a}$ & \\
\hline \multirow{4}{*}{$\begin{array}{l}\text { Magnesium } \\
\text { (Mg) }\end{array}$} & Zero & $1.49 \pm 0.07 \mathrm{a}$ & $1.49 \pm 0.06 \mathrm{a}$ & $1.60 \pm 0.02 \mathrm{a}$ & $1.53 \pm 0.03 \mathrm{c}$ \\
\hline & Milk 25\% & $1.87 \pm 0.08 b$ & $1.91 \pm 0.04 \mathrm{~b}$ & $2.21 \pm 0.100 \mathrm{a}$ & $2.00 \pm 0.04 \mathrm{~b}$ \\
\hline & Milk 50\% & $2.08 \pm 0.04 \mathrm{c}$ & $2.20 \pm 0.05 \mathrm{~b}$ & $2.85 \pm 0.07 \mathrm{a}$ & $2.38 \pm 0.04 \mathrm{a}$ \\
\hline & Mean $\pm S D$ & $1.81 \pm 0.03 \mathrm{~b}$ & $1.87 \pm 0.01 \mathrm{~b}$ & $2.23 \pm 0.05 \mathrm{a}$ & \\
\hline \multirow{4}{*}{ Iron (Fe) } & Zero & $1.91 \pm 0.05 \mathrm{c}$ & $2.19 \pm 0.07 \mathrm{~b}$ & $2.61 \pm 0.02 \mathrm{a}$ & $2.24 \pm 0.01 \mathrm{c}$ \\
\hline & Milk 25\% & $2.09 \pm 0.03 \mathrm{c}$ & $2.42 \pm 0.12 \mathrm{~b}$ & $2.86 \pm 0.05 \mathrm{a}$ & $2.46 \pm 0.05 \mathrm{~b}$ \\
\hline & Milk 50\% & $2.23 \pm 0.04 \mathrm{c}$ & $2.77 \pm 0.08 \mathrm{~b}$ & $2.94 \pm 0.03 \mathrm{a}$ & $2.65 \pm 0.02 \mathrm{a}$ \\
\hline & Mean \pm SD & $2.08 \pm 0.01 \mathrm{c}$ & $2.46 \pm 0.07 \mathrm{~b}$ & $2.80 \pm 0.04 \mathrm{a}$ & \\
\hline
\end{tabular}

Values are expressed as the mean standard deviation of three determinations

a b c d e Letters indicate significant differences between date compote treatments 


\section{Egyptian J. of Nutrition Vol. XXXIII No. 2 (2018)}

Table (6): Essential amino acids (mg/100 $\mathrm{g}$ on dry weight) of date compote made from different levels of milk and dibs

\begin{tabular}{|c|c|c|c|c|c|}
\hline \multirow{2}{*}{$\begin{array}{c}\text { Essential } \\
\text { amino acids }\end{array}$} & \multirow{2}{*}{ Milk Treatments } & \multicolumn{3}{|c|}{ Treatments of sugar replacer } & \multirow{2}{*}{ Mean $\pm S D$} \\
\hline & & Zero dibs & $50 \%$ dibs & $100 \%$ dibs & \\
\hline \multirow{4}{*}{ Histidine } & Zero milk & $19.77 \pm 0.39 \mathrm{c}$ & $20.91 \pm 0.41 \mathrm{~b}$ & $21.69 \pm 0.17 \mathrm{a}$ & $20.79 \pm 0.89 \mathrm{c}$ \\
\hline & Milk 25\% & $22.37 \pm 0.17 \mathrm{c}$ & $22.83 \pm 0.12 b$ & $23.35 \pm 0.12 \mathrm{a}$ & $22.85 \pm 0.44 b$ \\
\hline & Milk 50\% & $23.65 \pm 0.17 \mathrm{c}$ & $23.99 \pm 0.11 \mathrm{~b}$ & $24.39 \pm 0.16 \mathrm{a}$ & $24.01 \pm 0.35 \mathrm{a}$ \\
\hline & Mean \pm SD & $21.93 \pm 0.11 \mathrm{c}$ & $22.58 \pm 0.13 \mathrm{~b}$ & $23.14 \pm 0.06 \mathrm{a}$ & \\
\hline \multirow{4}{*}{ Isoleucine } & Zero & $35.38 \pm 0.46 \mathrm{c}$ & $37.26 \pm 0.31 \mathrm{~b}$ & $39.08 \pm 0.43 \mathrm{a}$ & $37.24 \pm 1.64 \mathrm{c}$ \\
\hline & Milk $25 \%$ & $37.10 \pm 0.23 \mathrm{c}$ & $38.48 \pm 0.77 b$ & $39.99 \pm 0.72 \mathrm{a}$ & $38.52 \pm 1.36 \mathrm{~b}$ \\
\hline & Milk 50\% & $39.11 \pm 0.37 \mathrm{~b}$ & $39.42 \pm 0.47 \mathrm{~b}$ & $41.67 \pm 0.16 \mathrm{a}$ & $40.07 \pm 1.25 \mathrm{a}$ \\
\hline & Mean \pm SD & $37.20 \pm 0.19 \mathrm{c}$ & $38.39 \pm 0.13 b$ & $40.25 \pm 0.42 \mathrm{a}$ & \\
\hline \multirow{4}{*}{ Leucine } & Zero & $46.13 \pm 0.29 \mathrm{c}$ & $47.21 \pm 0.61 \mathrm{~b}$ & $48.81 \pm 0.48 \mathrm{a}$ & $47.39 \pm 1.24 \mathrm{c}$ \\
\hline & Milk 25\% & $48.10 \pm 0.18 \mathrm{c}$ & $49.61 \pm 0.29 \mathrm{~b}$ & $51.01 \pm 0.19 \mathrm{a}$ & $49.57 \pm 1.27 b$ \\
\hline & Milk 50\% & $49.44 \pm 0.18 \mathrm{c}$ & $51.44 \pm 0.24 \mathrm{~b}$ & $52.92 \pm 0.49 a$ & $51.27 \pm 1.54 \mathrm{a}$ \\
\hline & Mean \pm SD & $47.89 \pm 0.12 \mathrm{c}$ & $49.42 \pm 0.19 \mathrm{~b}$ & $50.91 \pm 0.36 \mathrm{a}$ & \\
\hline \multirow{4}{*}{ Lysine } & Zero & $82.68 \pm 0.98 \mathrm{c}$ & $84.40 \pm 0.72 b$ & $85.89 \pm 0.32 \mathrm{a}$ & $84.32 \pm 1.53 \mathrm{c}$ \\
\hline & Milk 25\% & $85.07 \pm 0.25 \mathrm{a}$ & $86.29 \pm 0.27 \mathrm{a}$ & $86.36 \pm 1.70 \mathrm{a}$ & $85.91 \pm 1.07 \mathrm{~b}$ \\
\hline & Milk 50\% & $86.91 \pm 0.17 \mathrm{c}$ & $88.90 \pm 0.21 \mathrm{~b}$ & $89.66 \pm 0.38 \mathrm{a}$ & $88.49 \pm 1.25 \mathrm{a}$ \\
\hline & Mean \pm SD & $84.89 \pm 0.46 \mathrm{c}$ & $86.53 \pm 0.24 \mathrm{~b}$ & $87.30 \pm 0.42 \mathrm{a}$ & \\
\hline \multirow{4}{*}{ Methionine } & Zero & $48.29 \pm 0.35 \mathrm{c}$ & $50.25 \pm 0.66 \mathrm{~b}$ & $52.29 \pm 0.36 \mathrm{a}$ & $50.27 \pm 1.78 \mathrm{c}$ \\
\hline & Milk 25\% & $50.15 \pm 0.43 \mathrm{c}$ & $50.99 \pm 0.08 \mathrm{~b}$ & $53.81 \pm 0.51 \mathrm{a}$ & $51.65 \pm 1.69 b$ \\
\hline & Milk 50\% & $52.55 \pm 0.76 \mathrm{~b}$ & $52.55 \pm 0.76 \mathrm{~b}$ & $55.70 \pm 0.50 \mathrm{a}$ & $53.60 \pm 1.68 \mathrm{a}$ \\
\hline & Mean $\pm S D$ & $50.33 \pm 0.31 \mathrm{c}$ & $51.26 \pm 0.28 \mathrm{~b}$ & $53.93 \pm 0.26 \mathrm{a}$ & \\
\hline \multirow{4}{*}{$\begin{array}{c}\text { Phenylalanin } \\
\text { e }\end{array}$} & Zero & $41.23 \pm 0.31 \mathrm{c}$ & $43.26 \pm 0.28 \mathrm{~b}$ & $44.57 \pm 0.43 \mathrm{a}$ & $43.02 \pm 1.49 \mathrm{c}$ \\
\hline & Milk 25\% & $43.37 \pm 0.34 \mathrm{c}$ & $45.47 \pm 0.27 \mathrm{~b}$ & $47.02 \pm 0.15 \mathrm{a}$ & $45.29 \pm 1.60 \mathrm{~b}$ \\
\hline & Milk 50\% & $45.95 \pm 0.66 \mathrm{~b}$ & $46.56 \pm 0.20 \mathrm{~b}$ & $48.24 \pm 0.35 \mathrm{a}$ & $46.92 \pm 1.10 \mathrm{a}$ \\
\hline & Mean $\pm S D$ & $43.52 \pm 0.22 \mathrm{c}$ & $45.10 \pm 0.07 \mathrm{~b}$ & $46.61 \pm 0.19 a$ & \\
\hline \multirow{4}{*}{ Tryptophan } & Zero & $38.86 \pm 0.30 \mathrm{c}$ & $40.14 \pm 0.40 \mathrm{~b}$ & $41.39 \pm 0.40 \mathrm{a}$ & $40.13 \pm 1.14 \mathrm{c}$ \\
\hline & Milk 25\% & $40.11 \pm 0.31 \mathrm{c}$ & $41.48 \pm 0.14 \mathrm{~b}$ & $42.99 \pm 0.40 \mathrm{a}$ & $41.53 \pm 1.28 b$ \\
\hline & Milk 50\% & $41.37 \pm 0.21 \mathrm{c}$ & $43.02 \pm 0.07 \mathrm{~b}$ & $45.30 \pm 0.41 \mathrm{a}$ & $43.23 \pm 1.72 \mathrm{a}$ \\
\hline & Mean $\pm S D$ & $40.11 \pm 0.23 \mathrm{c}$ & $41.54 \pm 0.07 \mathrm{~b}$ & $43.23 \pm 0.12 \mathrm{a}$ & \\
\hline \multirow{4}{*}{ Valine } & Zero & $58.74 \pm 0.58 \mathrm{c}$ & $60.23 \pm 0.10 \mathrm{~b}$ & $62.25 \pm 0.39 a$ & $60.41 \pm 1.57 \mathrm{c}$ \\
\hline & Milk 25\% & $60.02 \pm 0.31 \mathrm{c}$ & $62.96 \pm 0.42 \mathrm{~b}$ & $65.47 \pm 0.25 \mathrm{a}$ & $62.82 \pm 2.38 \mathrm{~b}$ \\
\hline & Milk 50\% & $61.98 \pm 0.14 \mathrm{c}$ & $65.28 \pm 0.37 \mathrm{~b}$ & $67.34 \pm 0.35 \mathrm{a}$ & $64.87 \pm 2.36 \mathrm{a}$ \\
\hline & Mean $\pm S D$ & $60.25 \pm 0.10 \mathrm{c}$ & $62.82 \pm 0.12 b$ & $65.02 \pm 0.29 \mathrm{a}$ & \\
\hline
\end{tabular}

Values are expressed as the mean standard deviation of three determinations. 
Ferweez, $\mathrm{H}$ and $\mathrm{H}$. A. Ismail

Table (7): Non-essential amino acids ( $\mathrm{mg} / 100 \mathrm{~g}$ on dry weight) of date compote made from different levels of milk and dibs

\begin{tabular}{|c|c|c|c|c|c|}
\hline \multirow{2}{*}{$\begin{array}{l}\text { Non essential } \\
\text { amino acids }\end{array}$} & \multirow{2}{*}{$\begin{array}{c}\text { Milk } \\
\text { Treatments }\end{array}$} & \multicolumn{3}{|c|}{ Treatments of sugar replacer } & \multirow{2}{*}{ Mean $\pm S D$} \\
\hline & & Zero dibs & $50 \%$ dibs & $100 \%$ dibs & \\
\hline \multirow{4}{*}{ Alanine } & Zero milk & $80.27 \pm 0.99 \mathrm{a}$ & $80.06 \pm 0.19 a$ & $80.16 \pm 0.19 a$ & $80.16 \pm 0.52 \mathrm{c}$ \\
\hline & Milk 25\% & $81.55 \pm 0.28 a$ & $81.42 \pm 0.10 \mathrm{a}$ & $81.50 \pm 0.07 a$ & $81.49 \pm 0.16 b$ \\
\hline & Milk 50\% & $82.92 \pm 0.29 \mathrm{a}$ & $82.92 \pm 0.04 \mathrm{a}$ & $83.25 \pm 0.06 a$ & $83.03 \pm 0.22 \mathrm{a}$ \\
\hline & Mean \pm SD & $81.58 \pm 0.38 \mathrm{a}$ & $81.47 \pm 0.04 \mathrm{a}$ & $81.64 \pm 0.04 \mathrm{a}$ & \\
\hline \multirow{4}{*}{ Arginine } & Zero & $67.82 \pm 0.72 \mathrm{a}$ & $67.90 \pm 0.75 a$ & $68.08 \pm 0.77 a$ & $67.94 \pm 0.66 \mathrm{c}$ \\
\hline & Milk 25\% & $69.16 \pm 0.19 \mathrm{a}$ & $69.35 \pm 0.45 \mathrm{a}$ & $69.54 \pm 0.53 \mathrm{a}$ & $69.35 \pm 0.39 \mathrm{~b}$ \\
\hline & Milk 50\% & $70.70 \pm 0.22 \mathrm{a}$ & $69.96 \pm 1.89 \mathrm{a}$ & $71.29 \pm 0.15 \mathrm{a}$ & $70.65 \pm 1.12 \mathrm{a}$ \\
\hline & Mean \pm SD & $69.23 \pm 0.27 \mathrm{a}$ & $69.07 \pm 0.61 \mathrm{a}$ & $69.64 \pm 0.16 \mathrm{a}$ & \\
\hline \multirow{4}{*}{ Aspartic \% } & Zero & $81.17 \pm 0.21 \mathrm{a}$ & $81.44 \pm 0.16 \mathrm{a}$ & $82.30 \pm 1.25 \mathrm{a}$ & $81.63 \pm 0.82 \mathrm{c}$ \\
\hline & Milk 25\% & $83.34 \pm 0.35 \mathrm{a}$ & $83.63 \pm 0.31 \mathrm{a}$ & $83.78 \pm 0.20 \mathrm{a}$ & $83.58 \pm 0.32 b$ \\
\hline & Milk $50 \%$ & $85.12 \pm 0.21 \mathrm{a}$ & $84.00 \pm 2.31 \mathrm{a}$ & $85.62 \pm 0.15 \mathrm{a}$ & $84.91 \pm 1.37 \mathrm{a}$ \\
\hline & Mean $\pm S D$ & $83.21 \pm 0.24 \mathrm{a}$ & $83.02 \pm 0.74 \mathrm{a}$ & $83.90 \pm 0.50 \mathrm{a}$ & \\
\hline \multirow{4}{*}{ Cysteine } & Zero & $46.97 \pm 0.35 \mathrm{a}$ & $47.25 \pm 0.40 \mathrm{a}$ & $47.69 \pm 0.35 a$ & $47.30 \pm 0.45 \mathrm{c}$ \\
\hline & Milk 25\% & $49.56 \pm 0.58 \mathrm{~b}$ & $50.06 \pm 0.57 \mathrm{ab}$ & $50.68 \pm 0.18 \mathrm{a}$ & $50.10 \pm 0.64 \mathrm{~b}$ \\
\hline & Milk 50\% & $51.73 \pm 0.10 \mathrm{c}$ & $52.10 \pm 0.25 \mathrm{~b}$ & $52.77 \pm 0.17 \mathrm{a}$ & $52.20 \pm 0.49 \mathrm{c}$ \\
\hline & Mean $\pm S D$ & $49.42 \pm 0.05 \mathrm{c}$ & $49.80 \pm 0.06 \mathrm{~b}$ & $50.38 \pm 0.11 \mathrm{a}$ & \\
\hline \multirow{4}{*}{ Glutamic } & Zero & $61.27 \pm 0.31 \mathrm{a}$ & $61.71 \pm 0.28 \mathrm{a}$ & $61.71 \pm 0.28 \mathrm{a}$ & $61.56 \pm 0.34 \mathrm{c}$ \\
\hline & Milk 25\% & $63.46 \pm 0.23 \mathrm{a}$ & $63.77 \pm 0.20 \mathrm{a}$ & $63.77 \pm 0.20 \mathrm{a}$ & $63.66 \pm 0.24 \mathrm{~b}$ \\
\hline & Milk 50\% & $64.89 \pm 0.33 \mathrm{~b}$ & $65.63 \pm 0.12 \mathrm{a}$ & $65.63 \pm 0.12 \mathrm{a}$ & $65.38 \pm 0.41 \mathrm{a}$ \\
\hline & Mean \pm SD & $63.20 \pm 0.14 \mathrm{~b}$ & $63.70 \pm 0.07 \mathrm{a}$ & $63.70 \pm 0.07 a$ & \\
\hline \multirow{4}{*}{ Proline } & Zero & $82.47 \pm 1.19 \mathrm{~b}$ & $83.84 \pm 0.21 \mathrm{ab}$ & $85.02 \pm 0.18 \mathrm{a}$ & $83.78 \pm 1.26 \mathrm{c}$ \\
\hline & Milk 25\% & $85.90 \pm 0.26 \mathrm{~b}$ & $86.26 \pm 1.08 \mathrm{~b}$ & $87.62 \pm 0.29 \mathrm{a}$ & $86.59 \pm 0.97 b$ \\
\hline & Milk 50\% & $87.81 \pm 0.42 \mathrm{c}$ & $89.08 \pm 0.14 \mathrm{~b}$ & $90.44 \pm 0.12 \mathrm{a}$ & $89.11 \pm 1.16 \mathrm{a}$ \\
\hline & Mean \pm SD & $85.40 \pm 0.61 \mathrm{c}$ & $86.39 \pm 0.34 \mathrm{~b}$ & $87.69 \pm 0.19 \mathrm{a}$ & \\
\hline \multirow{4}{*}{ Serine } & Zero & $73.45 \pm 0.48 b$ & $75.71 \pm 0.30 \mathrm{a}$ & $76.06 \pm 0.19 a$ & $75.07 \pm 1.26 \mathrm{c}$ \\
\hline & Milk 25\% & $74.79 \pm 0.21 \mathrm{c}$ & $76.74 \pm 0.16 \mathrm{~b}$ & $77.33 \pm 0.43 \mathrm{a}$ & $76.29 \pm 1.18 b$ \\
\hline & Milk 50\% & $75.71 \pm 0.35 \mathrm{c}$ & $77.17 \pm 0.09 \mathrm{~b}$ & $80.14 \pm 0.28 \mathrm{a}$ & $77.67 \pm 1.97 \mathrm{a}$ \\
\hline & Mean $\pm S D$ & $74.65 \pm 0.29 \mathrm{c}$ & $76.54 \pm 0.03 \mathrm{~b}$ & $77.84 \pm 0.19 a$ & \\
\hline \multirow{4}{*}{ Tyrosine } & Zero & $78.10 \pm 0.16 \mathrm{c}$ & $79.95 \pm 0.23 \mathrm{~b}$ & $82.17 \pm 0.56 \mathrm{a}$ & $80.07 \pm 1.79 \mathrm{c}$ \\
\hline & Milk 25\% & $79.99 \pm 0.23 \mathrm{c}$ & $81.42 \pm 0.18 \mathrm{~b}$ & $83.64 \pm 0.10 \mathrm{a}$ & $81.68 \pm 1.60 \mathrm{~b}$ \\
\hline & Milk 50\% & $81.26 \pm 0.29 \mathrm{c}$ & $82.68 \pm 0.63 \mathrm{~b}$ & $84.33 \pm 0.42 \mathrm{a}$ & $82.75 \pm 1.39 \mathrm{a}$ \\
\hline & Mean $\pm S D$ & $79.78 \pm 0.15 c$ & $81.35 \pm 0.09 \mathrm{~b}$ & $\pm 0.18 \mathrm{a}$ & \\
\hline
\end{tabular}




\section{Egyptian J. of Nutrition Vol. XXXIII No. 2 (2018)}

Table (8): Sensory evaluation of date compote made from different levels of milk and dibs

\begin{tabular}{|c|c|c|c|c|c|}
\hline \multirow{2}{*}{ Property } & \multirow{2}{*}{$\begin{array}{c}\text { MILK } \\
\text { concentrate }\end{array}$} & \multicolumn{3}{|c|}{ Treatments of sugar replacer } & \multirow{2}{*}{ Mean $\pm S D$} \\
\hline & & Zero dibs & $50 \%$ dibs & $100 \%$ dibs & \\
\hline \multirow{4}{*}{$\begin{array}{c}\text { Flavour } \\
(10)\end{array}$} & Zero & $7.63 \pm 0.15 \mathrm{c}$ & $8.50 \pm 0.10 b$ & $9.07 \pm 0.06 \mathrm{a}$ & $8.40 \pm 0.63 \mathrm{c}$ \\
\hline & Milk 25\% & $8.17 \pm 0.06 \mathrm{c}$ & $8.97 \pm 0.06 b$ & $9.47 \pm 0.06 \mathrm{a}$ & $8.87 \pm 0.57 b$ \\
\hline & Milk 50\% & $8.53 \pm 0.06 \mathrm{c}$ & $9.33 \pm 0.06 \mathrm{~b}$ & $9.63 \pm 0.06 \mathrm{a}$ & $9.17 \pm 0.49 \mathrm{a}$ \\
\hline & Mean \pm SD & $8.11 \pm 0.05 c$ & $8.93 \pm 0.07 b$ & $9.39 \pm 0.02 \mathrm{a}$ & \\
\hline \multirow{4}{*}{$\begin{array}{c}\text { Appearance } \\
(10)\end{array}$} & Zero & $8.10 \pm 0.10 \mathrm{a}$ & $7.73 \pm 0.06 \mathrm{~b}$ & $7.53 \pm 0.06 \mathrm{c}$ & $7.79 \pm 0.26 \mathrm{~b}$ \\
\hline & Milk 25\% & $8.67 \pm 0.06 \mathrm{~b}$ & $9.17 \pm 0.06 \mathrm{a}$ & $8.73 \pm 0.06 \mathrm{~b}$ & $8.86 \pm 0.24 \mathrm{a}$ \\
\hline & Milk 50\% & $9.43 \pm 0.06$ a & $8.83 \pm 0.06 \mathrm{~b}$ & $8.47 \pm 0.06 \mathrm{c}$ & $8.91 \pm 0.43 \mathrm{a}$ \\
\hline & Mean \pm SD & $8.73 \pm 0.07 \mathrm{a}$ & $8.58 \pm 0.02 b$ & $8.24 \pm 0.02 \mathrm{c}$ & \\
\hline \multirow{4}{*}{$\begin{array}{c}\text { Taste } \\
(10)\end{array}$} & Zero & $7.40 \pm 0.10 \mathrm{c}$ & $8.13 \pm 0.06 \mathrm{~b}$ & $8.60 \pm 0.10 \mathrm{a}$ & $8.04 \pm 0.53 \mathrm{c}$ \\
\hline & Milk 25\% & $7.13 \pm 0.06 \mathrm{c}$ & $8.60 \pm 0.10 \mathrm{~b}$ & $8.97 \pm 0.06 \mathrm{a}$ & $8.23 \pm 0.84 b$ \\
\hline & Milk 50\% & $6.93 \pm 0.12 c$ & $9.03 \pm 0.06 \mathrm{~b}$ & $9.37 \pm 0.06 \mathrm{a}$ & $8.44 \pm 1.14 \mathrm{a}$ \\
\hline & Mean \pm SD & $7.16 \pm 0.05 c$ & $8.59 \pm 0.07 b$ & $8.98 \pm 0.07 \mathrm{a}$ & \\
\hline \multirow{4}{*}{$\begin{array}{c}\text { Consistency } \\
\text { (10) }\end{array}$} & Zero & $8.57 \pm 0.06 \mathrm{c}$ & $8.77 \pm 0.06 \mathrm{~b}$ & $9.07 \pm 0.06 \mathrm{~b}$ & $8.80 \pm 0.22 \mathrm{c}$ \\
\hline & Milk 25\% & $8.87 \pm 0.06 \mathrm{c}$ & $9.13 \pm 0.06 \mathrm{~b}$ & $9.33 \pm 0.06 \mathrm{a}$ & $9.11 \pm 0.21 \mathrm{~b}$ \\
\hline & Milk 50\% & $9.13 \pm 0.06 \mathrm{c}$ & $9.37 \pm 0.06 \mathrm{~b}$ & $9.57 \pm 0.06 \mathrm{a}$ & $9.36 \pm 0.19 \mathrm{a}$ \\
\hline & Mean \pm SD & $8.86 \pm 0.05 c$ & $9.09 \pm 0.02 b$ & $9.32 \pm 0.02 \mathrm{a}$ & \\
\hline \multirow{4}{*}{$\begin{array}{c}\text { Overall } \\
\text { acceptance } \\
\text { (40) }\end{array}$} & Zero & $31.70 \pm 0.30 \mathrm{c}$ & $33.13 \pm 0.06 \mathrm{~b}$ & $34.27 \pm 0.06 \mathrm{a}$ & $33.03 \pm 1.12 \mathrm{c}$ \\
\hline & Milk 25\% & $32.83 \pm 0.06 \mathrm{c}$ & $35.87 \pm 0.23 \mathrm{~b}$ & $36.50 \pm 0.00 \mathrm{a}$ & $35.07 \pm 1.70 \mathrm{~b}$ \\
\hline & Milk 50\% & $34.03 \pm 0.06 \mathrm{c}$ & $36.57 \pm 0.15 \mathrm{~b}$ & $37.03 \pm 0.21 \mathrm{a}$ & $35.88 \pm 1.40 \mathrm{a}$ \\
\hline & Mean \pm SD & $32.86 \pm 0.12 \mathrm{c}$ & $35.19 \pm 0.10 \mathrm{~b}$ & $35.93 \pm 0.06 \mathrm{a}$ & \\
\hline
\end{tabular}

Values are expressed as the mean standard deviation of three determinations

a b c d e Letters indicate significant differences between date compote treatments 
Ferweez, $\mathrm{H}$ and $\mathrm{H}$. A. Ismail

\section{References}

Abbes, F., Kchaou, W., Blecker, C., Ongena, M., Lognay, G., Attia, H. \&Besbes, S. (2013).

Effect of processing conditions on phenolic compounds \& antioxidant properties of date syrup".Industrial crop and products , 44( 1 ): 634-642.

Al-Farsi, M. and Lee, C. Y.(2008).

Nutritional and Functional Properties of Dates: A Review. Food sci. and nutrition, 48 (10):877-887 .

\section{Al-Farsi M, Alasalvar C, Al-Abid M, Al-Shoaily K, Al-Amry M and} Al-Rawahy F (2007).

Compositional and functional characteristics of dates, syrups, and their by-products. Food Chem. 104(3): 943-947.

Al-Hooti, S. , Sidhu, J.S., Qabazard, H.(1997).

Physicochemical characteristics of five date fruit cultivars grown in the United ArabEmirates, Plant Foods Hum. Nutr, 50 ( 2 ):101-113.

Al-Shahib, W. and Marshall, R. J. (2003).

The fruit of the date: it's possible as the best food for the future", Int. J. food sci.Nutri., 54 (4): 247-259.

Amiri,H.S., Nateghi,L. and Berenji,S.(2014).

Effect of date syrup as a substitute for Sugar on physicochemical and sensory properties of ice cream. Inte. J. Biosci., 5 ( 7 ): 80-88. 


\section{Egyptian J. of Nutrition Vol. XXXIII No. 2 (2018)}

AOAC (2005).

Official Methods of Analysis of Association of Official Analytical Chemist International, Washington (D.C.).

Assirey,E.A.R. (2015).

Nutritional composition of fruit of 10 date palm (Phoenix dactylifera L.) cultivars grown in Saudi Arabia. J. Taibah Univ. for Sci., 9 ( 1 ) : 75-79.

Barłowska, J., Szwajkowska, M. Litwi'nczuk, Z.and Król, J.(2011). Nutritional Value and Technological Suitability of Milk from Various Animal Species Used for Dairy Production. Food Science and Food Safety , 10 (6 ) :291-302.

Besbes, S., Drira, L., Blecker, C., Deroanne, C., and Attia, H.( 2009).

Adding value to hard date (Phoenix dactylifera L.): Compositional, functional and sensory characteristics of date jam. Food Chemistry, 112 (2): 406-411.

Borchani, C., Besbes, S., Blecker, C., Masmoudi, M., Baati , R. and Attia, H.(2010).

Chemical properties of 11 date cultivars and their corresponding fiber extracts. Afr. J. Biotechnol. 9 ( 26 ): 40964105.

\section{El-Nagga , E.A. Abd El-Tawab, Y.A.(2012).}

Compositional characteristics of date syrup extracted by different methods in some fermented dairy products. Annals of Agricultural Sci., 57 ( 1 ): 29-36. 
Ferweez, $H$ and $H$. A. Ismail

El-Sharnouby, A. Gamal , Salah M. Al-Eid and Mutlag M. Al Otaibi (2009).

Utilization of enzymes in the production of liquid sugar from dates. African Journal of Biochemistry Research. 3 (3):.041047.

El-Sohaimy S.A. and Hafez E.E. (2010).

Biochemical and Nutritional Characterizations of Date Palm Fruits (Phoenix dactylifera L.). J. Appli. Sci. Res., 6 ( 8 ): 1060-1067.

FAO ( 2017).

Food and Agriculture Organization of United Nations, Date palm production chapter 1 \& 2 downloaded from FAO website: www.FAO.org.

Gad, A. S., Kholif, A. M. \& Sayed, A. F. (2010).

Evaluation of the nutritional value of functional yogurt resulting fromcombination of date palm syrup \& skim milk. Am. J. Food Technol., 5 (4): 250-259.

Ghafari, Z., Hojjatoleslamy, M.,Shokrani, R. and Shariaty, M. A. (2013).

Use of date syrup as a sweetener in nonalcoholic beer: sensory and rheological assessment. J. Micro..., Biotechn. Food Sci. 3 (2): 182-184.

Gomez , K.A. and Gomez, A.A. (1983 ).

Statistical procedures for Agriculture research. A Wiley Inter Science Publication, John Wiley and Son, Inc. New York, USA . 


\section{Egyptian J. of Nutrition Vol. XXXIII No. 2 (2018)}

Guetouache, M., Guessas, B. and Medjekal, S.(2014).

Composition and nutritional value of raw milk. Issues Biol. Sci. Pharm. Res. 2(10):115-122.

Hasnaoui. A. , Elhoumaizi, M. A. , Borchani, C., Attia, H. and Besbes, S.(2012).

Physico- chemical characterization and associated antioxidant capacity of fiber concentrates from Moroccan date flesh. Indian J. Sci. and Techno.,5 (7 ) : 2954- 2960.

Ishurd, O. and Kennedy, J. F. (2005).

The anticancer activity of polysacharide prepared from Libyan dates (Phoenix dactylifera L.). Carbohydrate. Polymer, 59 (4): 531-535.

Ismail, M. M.(2015).

Which Is Better for Humans, Animal Milk or Vegetable Milk?. J Nutr. Health and Food Eng. 2(5): 67-68.

Kaushik, M. , Prakash, C. , Kumar, L.(2016).

Studies on Preparation of Rabri using Date Syrup as Sugar Substitute. Int. J. Sci. and Res., 5 (7):1183-1188.

Khan, M., Sarwar, A., Wahab, M., and Haleem, R. (2008).

Physio-chemical characterization of date varieties using multivariate analysis. J. Sci. Food and Agri., 88 ( 6 ): 10511059.

Lin, Y.C.; C.J. Washman and F.R. Vedemuthv (1982).

Vokaleris-Price and Hall methods for determining soluble tyrosine and tryptophan in Blue cheese. J. Dairy Sci., 65: 707. 
Ferweez, $\mathrm{H}$ and $\mathrm{H}$. A. Ismail

Miguel, A.; Fernando, M.; Gonzalo, G. and Manuela, J. (2003).

Total and soluble contents of calcium, magnesium, phosphorus and zinc in yoghurts. Food Chem.80 ( 4):573578.

Raiesi Ardali, F., Rahimi, E., Tahery, S. and Shariati , M. A.(2014). Production of a new drink by using date syrup and milk. Journal of Food Biosciences and Technology, 4 (2) : 67-72.

Ranganna, S. (1986).

Handbook of analysis and quality control for fruit and vegetable products. 2nd Ed. New Delhi: McGraw-Hill.

Rofehgari-Nejad, L., Pirrzifard, M., Asefi, N., Tabibi-Azar, M. and Ashrafi, R. (2010).

Comparative study of date syrup decolourization efficiency with ion exchange resins and bone chart, Asian J. Chem., 22 (1): 16-20.

Shafiei,M., Karimi,K. and Taherzadeh,M.J.(2010).

Palm Date Fibers: Analysis and Enzymatic Hydrolysis. Int. J. Mol. Sci. , 11(11): 4285-4296.

Soliman, G. Z. A(2005).

Comparison of chemical and mineral content of milk from human, cow, buffalo, camel and goat in Egypt. The Egyptian Journal of Hospital Medicine , 21: 116 - 130. 


\section{Egyptian J. of Nutrition Vol. XXXIII No. 2 (2018)}

Tang , Z.X. Shi, Lu-E and Aleid, S. M.(2014).

Date and their processing byproducts as substrates for bioactive compounds production. Braz. Arch. Biol. Technol. 57(5): 706-713.

Vakaleris, D.G. and W.V. Price (1959).

A rapid spectrophotometric method for measuring cheese ripening. J. Dairy Sci., 42:264. 


\title{
Ferweez, $\mathrm{H}$ and $\mathrm{H}$. A. Ismail
}

\section{تقييم كمبوت البلح المعد بمستويات مختلفة من الابس واللبن}

\author{
' حسين فرويزمحمد حسن ، و هثام عبد الرحمن اسماعيل \\ ' قسم علوم وتكنولوجيا الأغذية و قَسم علوم وتكنولوجيا الالبان

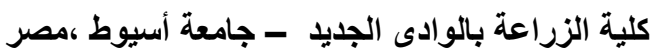

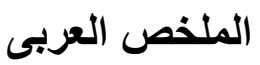

تدعيم كمبوت البلح باللبن (كمصدر للبروتين والدهن) و الدبس (كبديل للمحلول

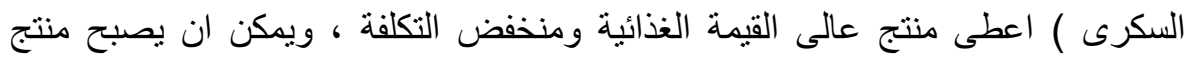
تصديرى للاستفادة من الكميات الكبيرة من التمور التى تمثل المنتج الرئيسى فى محافظة

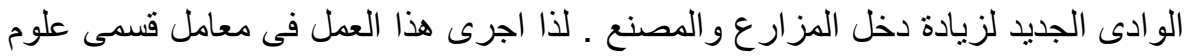
وتكنولوجيا الاغذية والالبان بكلية الزراعة بالوادى الجديد- جامعة اسيوط اثناء موسىى

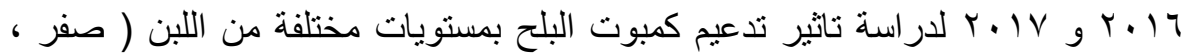

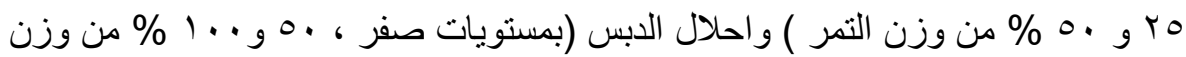
المحلول السكرى ) على الصفات الفيزوكيميائية و التقييم الحسى لكمبوت البلح .

\section{اوضحت النتائج المتحصل عليها الاتى :}

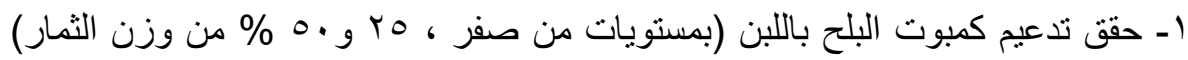

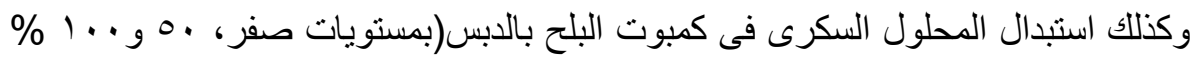
من وزن الثمار ) ناثثير معنويا على كل من :

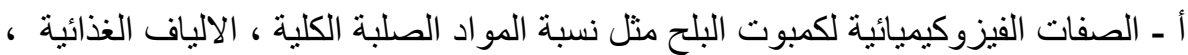

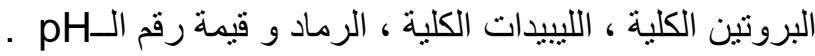
ب - كميات السكريات لكمبوت البلح مثل نسبة السكريات الكلية , السكريات المختزلة ، السكروز ، الجلوكوز ، الفركتوز عدا نسبة الجلوكوز / الفركتوز بالنسبة الى التدعيم باللبن لغالين 


\section{Egyptian J. of Nutrition Vol. XXXIII No. 2 (2018)}

ت ـ كميات العناصر المعنية لكمبوت البلح مثل كميات البوتاسيوم ، الصوديوم ،

$$
\text { الماضسيوم والحديد (ملليجم / · . } 1 \text { جم ). }
$$

ث - كميات الاحماض الامينية الاساسية لكمبوت البلح مثل احماض الهستدين ، ايزوليوسين ، ليوسين ، الليسين ، ميثيونين ، الفنيل الانين ، تربتوفان ، الفالين والاحماض

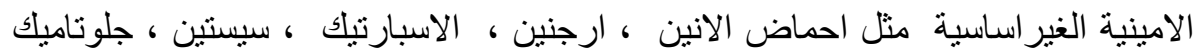

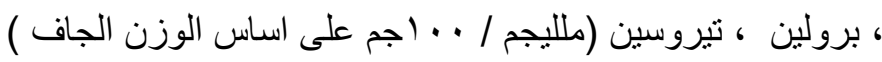

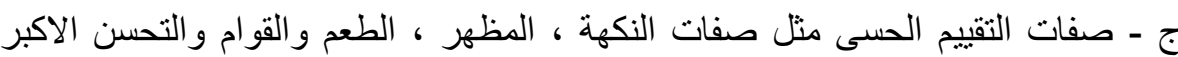
كان فى المظهر بالنسبة للتدعيم باللبن ، والتحسن الاكبر كان فى الطعم بالنسبة لاستبدال

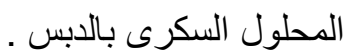
عموما من النتائح المتحصل عليها من هذا العمل نجد ان تصنيع كمبوت البلح المدعم باللبن

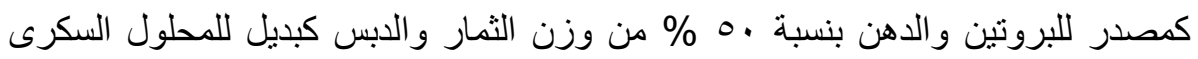
بنسبة ..1 \% من وزن المحلول السكرى كانت الافضل والاعلى فى القيمة الغذائية ويمكن تصديره للخار جلزيادة دخل المز ارع و المصنع. 